\title{
The Role of Banks in the Transmission of Monetary Policy
}

\author{
Joe Peek and Eric S. Rosengren
}

\begin{abstract}
The transmission of monetary policy, especially in light of recent events, has received increased attention, especially with respect to the efficacy of the bank lending channel. This paper summarizes the issues associated with isolating the bank lending channel and determining the extent to which it is operational. Evidence on the effectiveness of the bank lending channel is presented, both in the United States and abroad. The paper then provides observations about the likely consequences for the effectiveness of the lending channel of the changes in the financial environment associated with the recent financial crisis.
\end{abstract}

Keywords: bank lending channel, loan supply, monetary policy, financial crisis, bank regulation, financial innovation.

\section{JEL Classifications: E52, G21}

Joe Peek is a vice president of the Federal Reserve Bank of Boston and head of the financial section in the research department. Eric S. Rosengren is president of the Federal Reserve Bank of Boston. Their email addresses are, respectively, joe.peek@bos.frb.org and eric.rosengren@bos.frb.org.

This paper is a work in progress and is forthcoming in print in The Oxford Handbook of Banking, $2^{\text {nd }}$ edition, edited by Allen N. Berger, Philip Molyneux and John O. S. Wilson, and online at http://www.oxfordhandbooks.com/.

The views expressed in this paper are the authors' and do not necessarily reflect those of the Federal Reserve Bank of Boston, the Federal Reserve System, or the Federal Open Market Committee (FOMC).

This paper, which may be revised, is available on the web site of the Federal Reserve Bank of Boston at http://www.bostonfed.org/economic/ppdp/index.htm.

version of: September 9, 2013 


\section{Introduction}

While macroeconomists have traditionally focused on the role of inside money in the transmission of monetary policy, over the past two decades an increased emphasis has been placed on the other side of bank balance sheets. Although the traditional interest rate channel for the transmission of monetary policy remains intact, the importance of the credit channel in augmenting the impact of monetary policy on the economy has gained credibility. Still, while the broad credit channel version has gained widespread acceptance, the narrower bank lending channel remains somewhat controversial. The main points of contention are whether a shift in monetary policy affects bank loan supply, and, if it does, the extent to which a change in bank loan supply can affect economic activity. Here, we describe the mechanisms by which the banking system transmits changes in monetary policy and provide an overview of the evidence on the efficacy of the view that bank lending plays an important role in determining the magnitude of the effect of monetary policy on the economy.

Several factors may explain the renewed interest in the role played by bank lending in the transmission mechanism of monetary policy. First, financial innovation has resulted in a shift in the focus of monetary policy from a focus on money aggregates to a focus on interest rates, as the Federal Reserve relied on the federal funds rate as its policy instrument until hitting the zero lower bound in the recent financial crisis. Second, in the early 1990s, the U.S. experienced significant banking problems that resulted in banks limiting their lending as a result of capital constraints. ${ }^{1}$ Similar concerns with a bank 'capital crunch' help to explain some of the reaction of monetary policymakers to their own banking problems in countries as diverse as Japan, Sweden, and Argentina. ${ }^{2}$ Third, episodes of liquidity problems in the United States, such as those associated with the failure of Penn Central, the 1987 stock crash, the Long-Term Capital Management crisis, the events of 9/11, and the Lehman failure, have highlighted the important role of bank lending during liquidity and financial crises. ${ }^{3}$ Fourth, the concerns about the bank capital crunch of the early 1990s have once again been raised as

\footnotetext{
${ }^{1}$ See Calomiris (2014) for a discussion of earlier episodes and the role of banking distress in exacerbating adverse macroeconomic shocks.

2 See Caprio and Honohan (2014) for a thorough discussion of banking crises.

${ }^{3}$ See Strahan (2009) and Bouwman (2014) for a discussion of the important role of banks in providing 'funding' liquidity.
} 
numerous banks and nonbank lending institutions became capital constrained as a result of the credit problems that became apparent in August 2007.

The subsequent financial crisis caused countries from around the world to intervene in an effort to stabilize the banking system and credit markets more generally. In addition to the standard interest rate reductions, these interventions included significant capital injections, such as the Troubled Asset Relief Program (TARP) capital injections in the United States, and extensions of broad liability guarantees to ensure that banks would have the ability to roll over debt. Finally, as traditional interest rate policies became limited by the zero lower bound, countries increasingly looked to alternative monetary policy tools, with major central banks undertaking quantitative easing policies and engaging in forward guidance on interest rates. In the United States, the extensive use of lending facilities was adopted in an effort to stimulate lending by financial institutions with the intent, in some cases, to impact financial markets more broadly, for example the commercial paper and asset-backed commercial paper markets. While our recent experience has highlighted the observation that problems that generated major banking reforms in the past, for example concerns about asset-liability management and liquidity runs, were not unique to banks, the financial crisis has also focused attention on the importance of banks for the shadow banking market and in the securitization of assets, two areas badly disrupted by the crisis. However, another important lesson is that understanding the role of banks in lending and in financial markets more generally is critically important for explaining both the onset of the financial crisis and the severity of the ensuing economic crisis.

This paper provides an overview of recent research about the role played by bank lending in the transmission of monetary policy. The second section begins with a description of the mechanisms, under both the money view and the credit view, by which monetary policy is transmitted to the economy through the banking sector. The third section examines the empirical evidence on how bank lending responds to changes in monetary policy. This literature has focused both on changes in firms' borrowing and on changes in the amounts and composition of bank assets following a change in the stance of monetary policy. In particular, we discuss the evidence concerning which banks and which firms are likely to play key roles in transmitting monetary policy to the macroeconomy through the bank lending channel. This section also includes a discussion of how the effects emanating from 
the bank lending channel can be derailed by bank capital constraints that limit the extent to which banks are able to expand their balance sheets in response to an easing of monetary policy. The fourth section briefly reviews some of the literature on the role of banks in other countries, many of which are far more dependent on bank lending than is the United States. The fifth section discusses how the role of bank lending may have been altered by recent financial innovations and provides observations on the implications of the events associated with the recent financial crisis for the effectiveness of the bank lending channel. The final section provides some conclusions.

\section{How is monetary policy transmitted through the banking system?}

\section{Traditional interest rate, or money, view}

The traditional interest rate, or money, view of the transmission of monetary policy focuses on the liability side of bank balance sheets. The important role played by banks in this transmission mechanism arises from the reserve requirement constraint faced by banks. Because banks rarely hold significant excess reserves, the reserve requirement constraint is typically considered to be binding at all times. ${ }^{4}$ Thus, shifts in monetary policy that change the quantity of outside money result in changes in the quantity of inside money in the form of the reservable deposits that can be created by the banking system.

The transmission mechanism functions as follows. When the monetary authority undertakes open-market operations in order to tighten monetary policy (by selling securities), the banking industry experiences a decline in reserves. The fractional reserve system then forces banks (as a whole) to reduce reservable deposits in order to continue to meet the reserve requirement. This shock, which is exogenous to the banking sector, thus constrains bank behavior. To induce households to hold smaller amounts of reservable deposits (transactions accounts), interest rates on other deposits and non-deposit alternatives must rise. That is, since the supply of transactions deposits has declined relative to the supply of alternative assets, interest rates on these alternative assets would have to rise to clear the market for transactions deposits. As the increase in the short-term interest

\footnotetext{
${ }^{4}$ While that accurately describes non-crisis times, two recent notable exceptions are the episodes of quantitative easing policies undertaken by the Bank of Japan in response to the crises experienced by Japan in the 1990s and, in response to the most recent financial crisis, also by the Federal Reserve, the Bank of England, and the European Central Bank.
} 
rate is transmitted to longer term interest rates, aggregate demand declines. However, an important characteristic of the recent financial crisis has been the substantial expansion of excess reserves in the U.S. banking system. Consequently, with the reserve requirement failing to serve as a binding constraint on most institutions, an increasing focus has been placed on the important role of alternative transmission mechanisms.

\section{The broad credit channel}

The broad credit channel, also referred to as the balance sheet effect or financial accelerator, does not require that a distinction be drawn among the alternative sources of credit. Instead, it is predicated on credit market imperfections associated with asymmetric information and moral hazard problems. Research on the credit channel was motivated, in large part, by the puzzle that monetary policy shocks that had had relatively small effects on long-term real interest rates appeared to have had substantial effects on aggregate demand. This literature attributes the magnification, or propagation, of monetary policy shocks to frictions in the credit markets (see, for example, Gertler and Gilchrist 1993; Cecchetti 1995; Hubbard 1995; Bernanke and Gertler 1995; Bernanke, Gertler, and Gilchrist 1996; and Oliner and Rudebusch 1996a). Because of the information asymmetries between borrowers and lenders, external finance is an imperfect substitute for a firm's internal funds.

The broad credit channel posits that an increase in interest rates associated with a tightening of monetary policy causes a deterioration in firm health, in terms of both net income and net worth. A firm's net income is impaired both because its interest costs rise and because its revenues deteriorate as the tighter monetary policy slows the economy. A firm's net worth is adversely impacted as the lower cash flows emanating from the firm's assets are discounted using the higher interest rates associated with the tightening of monetary policy. The deterioration in the firm's net income and the reduction in the collateral value of the firm's assets, in turn, cause an increase in the external finance premium that must be paid by the firm for all sources of external finance. This increase in the cost of external funds for borrowers over and above the risk-free interest rate then results in a reduction in aggregate demand in addition to that due to the increase in the risk-free interest rate associated with the interest rate channel of the transmission of monetary policy. 


\section{The bank lending channel}

With the bank lending, or credit, view, in contrast to the money view, the focus of the transmission mechanism operating through bank balance sheets shifts from bank liabilities to bank assets. When monetary policy tightens, the reduction in available bank reserves forces banks to create fewer reservable deposits. Banks must then either replace the lost reservable deposits with nonreservable liabilities, or shrink their assets, such as loans and securities, in order to keep total assets in line with the reduced volume of liabilities. Typically, one would expect to observe some combination of these responses, although Romer and Romer (1990) question the extent to which banks, in an age of managed liabilities, are unable to easily replace reservable deposits. However, to the extent that banks are unable or unwilling to fully insulate their loan portfolio, the interest rate effect on aggregate demand is supplemented with an additional effect stemming from a reduction in the availability of bank loans that further slows aggregate demand.

In a simple world with three assets-money, government bonds, and bank loans-three conditions must be satisfied for the bank lending channel to be operational in the transmission of monetary policy (see, for example, Bernanke and Blinder 1988; and Kashyap and Stein 1994). First, as with the interest rate view, prices must not adjust fully and instantaneously to a change in the money supply. That is, money is not neutral, at least in the short run. Second, open-market operations must affect the supply of bank loans. Third, loans and bonds must not be perfect substitutes as a source of credit for at least some borrowers. Of course, the set of assets can be expanded to include private sector bonds and nonbank intermediated loans, in which case the narrower bank lending channel is distinguished from the broad credit channel by requiring that private sector bonds and nonbank intermediated loans not be perfect substitutes for bank loans as a source of credit for at least some borrowers. Because only the second and third conditions distinguish the bank lending view from the money view, and because substantial evidence exists that wages and prices are not perfectly flexible, it will be assumed for the purposes of this discussion that the first condition holds.

With respect to the second condition, when open-market operations reduce the quantity of bank reserves, the banking system has no choice but to reduce reservable deposits, given the reserve requirement. However, banks do have choices, and individual banks do differ 
with respect to how, and to what extent, they respond to this decline in reserves. Banks must raise nonreservable liabilities to replace the lost reservable deposits, reduce assets such as securities and loans, or make some combination of these two types of portfolio adjustments. To the extent that banks do not regard nonreservable sources of funds as perfect substitutes for reservable deposits, they will not fully replace the lost reservable deposits, and thus must shrink their assets in order to keep their total assets in line with their reduced volume of liabilities.

Asymmetric information and credit market frictions play an important role in determining how an individual bank responds on the liability side of its balance sheet. Banks primarily use uninsured nonreservable liabilities, such as large time deposits, as the marginal source of funds during a period of monetary policy tightening. However, the ease of raising large time deposits varies by bank. For example, one would expect that more transparent (for example, publicly traded), larger, and healthier banking organizations would have relatively better access to external (uninsured) funds, and thus would tend to replace a higher proportion of their lost reservable deposits, resulting in a relatively smaller shrinkage in their assets.

Given that some shrinkage in bank assets will occur, a bank must then decide on the distribution of that shrinkage across the various assets held in its portfolio. Because securities are relatively liquid and considered to be secondary reserves, one would certainly expect banks to shrink their holdings of securities. However, to the extent that banks do not consider securities and loans to be perfect substitutes in their asset portfolio, one would expect that at least part of the adjustment in assets would come from a shrinkage in the volume of their loan portfolio, although initially the loan portfolio might temporarily grow as a result of distress borrowing, as loan customers access credit from previously established loan commitments and lines of credit (Morgan 1998).

Asymmetric information and credit market frictions also play an important role in determining the extent to which firms consider bonds, or, more generally, publicly issued credit market instruments, and nonbank intermediated loans to be perfect substitutes for bank loans. That is, to distinguish the broad credit channel from the bank lending channel, one must address the degree to which borrowers consider nonbank sources of credit as perfect substitutes for bank loans. To the extent that nonbank sources of credit are perfect 
substitutes for bank loans from the viewpoint of borrowers, borrowers will merely substitute these alternative sources of credit for bank loans when a tightening of monetary policy reduces the availability of bank loans. In this case, one would observe no impact on aggregate demand arising from the reduction in bank credit beyond that due to the increase in the external finance premium associated with the broad credit channel.

Although nonbank financial intermediaries provide loans, open-market instruments are available for short-term credit, and trade credit is available to some firms, these alternative sources of credit are not perfect substitutes for bank credit for a variety of institutional reasons. With respect to the substitutability of intermediated loans and publicly issued credit market instruments, not all firms have access to public credit markets. In particular, smaller firms are unable to issue such debt because the issue size would be too small to outweigh the fixed costs of issuance at a reasonable interest rate. Similarly, firms that are sufficiently opaque or have a sufficiently low credit standing to require close monitoring by a financial intermediary would not have direct access to the credit markets. Still, even though large, highly rated firms can directly access public credit markets by issuing commercial paper, issuing unsecured commercial paper may still involve participation by banks, insofar as the issuing firms obtain third-party guarantees from banks to enhance the credit rating of the commercial paper in order to lower the interest cost to the firm.

Similarly, alternative sources of intermediated loans are not perfect substitutes for bank loans for at least some borrowers. While for firms bank loans share the attributes of many of the alternative forms of intermediated loans, there are important differences. For example, insurance companies are very active in the commercial real estate market and are important providers of term financing that allows them to better match the maturities of their assets and liabilities. Similarly, finance companies provide asset-backed financing-for example, for loans collateralized by inventories and accounts receivable. Yet, for a small, opaque firm with few tangible assets, bank loans may be the only source of an unsecured line of credit or of a loan secured by an asset that might not be easily commoditized. As a result, the clientele effect in bank lending results in many firms being bank dependent, with few alternatives to banks should their bank credit be curtailed. 


\section{Empirical evidence on the role of bank lending for the transmission of monetary policy}

Empirical researchers investigating the bank lending view face several challenges. First, they need to determine whether a change in monetary policy does affect bank lending. Then, if bank lending is affected, the issue becomes the extent to which shifts in bank loan supply do, in fact, affect aggregate demand. The difficulties in establishing the first point are twofold. First, to what extent are banks able to insulate their loan portfolios from monetary policy shocks by adjusting other components of their balance sheet? The second difficulty concerns identifying a bank-loan supply shock, insofar as a decline in bank loans following a tightening of monetary policy may simply reflect a decline in loan demand rather than a decline in the supply of loans.

\section{The effect of monetary policy on bank loan supply}

While the theoretical conditions required for bank loan supply to be affected by changes in monetary policy are clear, it is not straightforward empirically to disentangle shifts in loan supply from shifts in loan demand. At an aggregate level, Bernanke and Blinder (1992), among others, show that bank lending does contract when monetary policy becomes tighter. However, such an observed correlation may reflect a reduction in loan demand as the economy weakens in response to the tighter monetary policy, rather than reflecting a reduction in bank loan supply. Furthermore, even if one observed an initial increase in bank loans or a notable delay in the decline in bank loans following a tightening of monetary policy, such evidence would not necessarily conflict with an inward shift in bank loan supply in response to a tightening of monetary policy. For example, the initial response of firms to a tightening of monetary policy may be an increase in loan demand resulting from the need to finance the buildup of inventories, as aggregate demand initially declines faster than production. Even though banks may decrease loan supply immediately to borrowers without loan commitments, the total amount of bank loans may temporarily increase, as banks are forced to honor existing loan commitments (Morgan 1998). Thus, the endogeneity issues associated with using aggregate data for total loans make it impossible to obtain a clear answer.

Kashyap, Stein, and Wilcox (1993) provide an alternative approach for identifying an effect of monetary policy on bank loan supply, although the analysis is still based on 
aggregated data. They investigate the change in the mix of bank loans and commercial paper in the composition of firms' external finance, with the argument being that if the decline in loans is due to a general decline in credit demand associated with a slowing of the real economy, then demand for other types of credit should decline similarly. Finding that a tightening of monetary policy is associated with an increase in commercial paper issuance and a decline in bank loans, they conclude that a tightening of monetary policy does reduce bank loan supply rather than the decline in bank loans simply reflecting a reduction in credit demand as the economy slows. In the same vein, Ludvigson (1998) investigates the composition of automobile finance between bank and nonbank providers of credit. She finds that, in fact, a tightening of monetary policy reduces the relative supply of bank loans, consistent with the bank lending channel. In contrast, Oliner and Rudebusch (1996b) revisit the Kashyap, Stein, and Wilcox (1993) approach using a different measure of the mix of external finance and disaggregating the data into two separate components, one for small firms and one for large firms. They argue that their evidence is consistent with the broad credit channel rather than with the more narrowly defined bank lending channel. However, this only highlights the weaknesses associated with attempting to isolate bank loan supply shocks from shifts in credit demand using aggregate data. In fact, in their reply, Kashyap, Stein, and Wilcox (1996) close by suggesting that a more definitive answer will have to rely on an analysis using micro data at the individual bank and firm levels.

By advancing the analysis to focus on panel data, the literature has been able to obtain more definitive results about the impact of changes in monetary policy on bank loan supply. The key has turned out to be relating cross-sectional differences in bank, or banking organization, characteristics to differences in the extent to which banks were able to insulate their loan portfolios from a tightening of monetary policy. Two aspects of bank characteristics appear to have been the primary focus. First, the ability of banks to raise nonreservable liabilities to replace the lost reservable deposits is a key factor in determining the extent to which a bank must adjust its loan portfolio when monetary policy is tightened. Because these funds are, for the most part, uninsured liabilities, bank characteristics related to banks' access to external funds-for example, size, health, and direct access to capital markets-play an important role in determining the ability of banks to insulate their loan portfolios from the effects of changes in monetary policy. Second, because banks face a 
capital requirement constraint in addition to the reserve requirement constraint on their activities, banks may differ in their response to a change in the stance of monetary policy, depending on which constraint is more binding. If the capital ratio requirement is the binding constraint, easing the reserve requirement constraint through open market operations should have little, if any, effect on bank lending. That is, because the binding constraint has not been eased, expansionary monetary policy, at least if operating through the bank lending channel, would be like 'pushing on a string.'

Kashyap and Stein (1995) note that with a tightening of monetary policy and the associated loss in reservable deposits, it is costly for banks to raise uninsured deposits. However, banks differ in the degree to which they have access to external funds. Kashyap and Stein hypothesize that bank size is a reasonable proxy for the degree of access to uninsured liabilities, with smaller banks having more limited access, and thus having their loan portfolio impacted more by a tightening of monetary policy. Indeed, they find empirical support for the proposition that small banks are more responsive (shrink their loan portfolios by more) than large banks to a monetary policy tightening.

Subsequently, Kashyap and Stein (2000) extend their analysis of the relative ease with which banks can raise uninsured deposits following a monetary policy tightening, noting that the bank loan response will also differ depending on the liquidity position of the bank. A bank that finds it relatively costly to raise uninsured deposits but that has large securities holdings has the option of adjusting to the shrinkage of reservable deposits by selling some of its securities, while a less liquid bank may be forced to shrink its loan portfolio by a greater degree. In a large cross-section of banks, they find evidence that the loan portfolios of smaller, more illiquid banks are the most responsive to monetary policy shocks.

Campello (2002) distinguishes among these smaller banks based on whether the bank is affiliated with a large multibank holding company, finding that the lending of small banks that are affiliated with large multibank holding companies reacts less to a tightening of monetary policy than does the lending of similar small (standalone) banks that are not affiliated with multibank holding companies. Although this evidence indicates that small banks affiliated with multibank holding companies are better able to insulate their lending from a tightening of monetary policy, the extent to which this is due to the channeling of internal holding company funds to bank subsidiaries rather than due to the fact that large 
multibank holding companies have easier access to external funds is not clear. Campello tries to address this issue by using capital-to-asset ratios to distinguish among bank holding companies. Similarly, Kishan and Opiela (2000) use the capital-to-asset ratio as the proxy for a bank's ability to raise uninsured deposits, finding that the loan portfolios of wellcapitalized banks are less sensitive to monetary policy shocks than are those of poorly capitalized banks of the same size. However, for reasons discussed below, capitalconstrained banks may behave differently for reasons other than their ability to raise uninsured deposits.

Holod and Peek (2007) utilize the distinction between publicly traded and non-publicly traded banks to classify banks by the ease with which they can access external funds. They find that after controlling for size, capitalization, and other factors, the loan portfolios of publicly traded banks shrink less than those of non-publicly traded banks when monetary policy tightens due to the banks' ability to raise external funds, including by issuing large time deposits. Furthermore, as one would expect, when a distinction is made between tightening and easing monetary policy, the estimated effect can be attributed to the effects of monetary policy tightening (tightening a binding constraint) rather than to monetary policy easing (possibly pushing on a string).

While substantial evidence supports the existence of an operational lending channel that amplifies the transmission of monetary policy, recent studies have suggested that the lending channel may have been weakened in recent years by developments in financial markets that allow banks to be less dependent on reservable deposits to fund their lending. For example, Loutskina and Strahan (2009) argue that growth in loan securitization, in particular the expansion of the secondary mortgage market, has weakened the transmission of monetary policy through the lending channel by increasing bank balance sheet liquidity. Similarly, Cetorelli and Goldberg (2012) argue that the domestic amplification of monetary policy through the lending channel has been mitigated by the increasing globalization of banking. Banking organizations with international operations are able, at least partially, to insulate themselves from domestic liquidity shocks, such as from a monetary policy tightening, though the cross-border operation of their internal capital markets. That is, multinational banks can react to a tightening of monetary policy by using internal flows of funds to offset the impact on their domestic banks. On the other hand, this mechanism also 
suggests that the total effect of the lending channel has been understated by focusing only on domestic lending, insofar as changes in monetary policy are propagated internationally through the internal capital markets of global banks.

The second important characteristic of banks that can affect the extent to which the bank lending channel is operative is whether banks face a binding capital constraint. As a result of the 'headwinds in monetary policy' noted by Chairman Greenspan during the recovery from the 1990 recession, a variety of authors have examined the impact that significant bank health problems can have on the transmission of monetary policy. For example, Peek and Rosengren (1995a) examine the impact that being capital constrained had on a bank's ability to lend during the period of significant banking problems in the early 1990s in New England. Using a simple static model, they show that banks facing a binding capital constraint are limited in altering the size of their balance sheet, restricting the ability of capital-constrained banks to respond to monetary policy shocks. They document that experiencing an adverse capital shock that makes the capital constraint binding will cause banks to shrink both assets and liabilities. Peek and Rosengren (1995a) also show that the behavior of capital-constrained banks in New England differed from that of unconstrained banks, with the loan portfolios of unconstrained banks responding more to monetary policy shocks than those of the capital-constrained banks.

In a subsequent study, Peek and Rosengren (1995b) focus on the direct impact of the enforcement of capital regulations by bank supervisors on the ability of capital-constrained banks to lend, and thus to be able to increase loans in response to an easing of monetary policy. They examine the impact on bank lending of formal regulatory actions (cease and desist orders and written agreements) imposed on banks that experienced asset quality problems. They find that the enforcement actions by bank regulators included explicit capital targets that needed to be achieved over a short time frame. The result was an immediate and significant reduction in bank loan portfolios associated with the imposition of the enforcement action that persisted for some time thereafter while the bank continued to operate under the enforcement action.

Alternatively, banks can become capital constrained as a consequence of changes in capital regulations. A number of authors have examined whether such changes can cause banks to be particularly responsive to their capital constraint, and, by implication, less 
responsive to changes in monetary policy. For example, Hall (1993) finds that the introduction of the Basel I Accord had a significant impact on bank portfolios. Hancock and Wilcox (1994) also find that the implementation of the Basel I Accord affected banks' willingness to lend. However, Berger and Udell (1994) do not find evidence that the Basel I Accord created a bank capital crunch. More recently, a concern raised with the proposed Basel II Accord has been that the new capital regulations would magnify potential capital constraints during recessions (for example, Kashyap and Stein 2004), making banks less responsive to an easing of monetary policy. Thus, a very real concern with the effectiveness of the bank lending channel, and thus the overall effectiveness of monetary policy, is whether banks are capital constrained at the time of an easing of monetary policy.

\section{Real effects of shifts in bank loan supply}

Given that the empirical evidence generally supports the proposition that banks, particularly those that may find it relatively expensive to raise uninsured liabilities, respond to a monetary policy tightening by reducing loans, we turn to the next link in the bank lending channel mechanism. For the reduction in bank loans to have an impact on economic activity, firms must not be able to easily substitute other sources of external finance when bank loan supply is cut back. Gertler and Gilchrist (1994) find, at a somewhat aggregated level, that the investment of an aggregate of small firms is more responsive to changes in monetary policy than is the investment of an aggregate of large firms, a set of firms that

presumably is less bank dependent. Similarly, Ludvigson (1998), comparing bank and nonbank sources of automobile loans, finds that the composition of automobile credit impacts automobile sales, even after controlling for the standard factors that probably impact automobile demand.

Additional evidence at an aggregate level is provided by Driscoll (2004), who uses a panel of state-level data to investigate the extent to which shocks to bank loan supply affect output. Using state-specific shocks to money demand as an instrumental variable to address the endogeneity problem, he does not find a meaningful effect of loan supply shocks on economic activity at the state level. Ashcraft (2006), similarly basing his analysis on statelevel data, attempts to exploit differences between standalone banks and banks affiliated with multibank holding companies in their degree of access to external funds in order to identify loan supply shocks related to changes in monetary policy. While he does find a 
difference between the two types of banks in their lending response to changes in monetary policy, he does not find a significant effect of these bank loan supply shocks on state income growth. In contrast, Ashcraft (2005), using the cross-guarantees of two failed Texas bank holding companies as his identification mechanism to address the endogeneity problems, finds that the failures of healthy banks forced by the cross-guarantee provisions were associated with reduced local economic activity. This suggests that bank lending is special, insofar as it appears that other lenders (even other banks) did not fill the gap created by the sharp reduction in lending by the failed banks, and is consistent with an operative lending channel.

Another approach that provides direct evidence that a reduction in bank loan supply adversely affects macroeconomic activity is provided by Peek and Rosengren (2000). Using the banking problems in Japan as the source of an exogenous loan supply shock in the United States, they are able to avoid the common endogeneity problem faced by studies that rely on domestic shocks to bank loan supply. Furthermore, by focusing on commercial real estate loans that tend to have local or regional markets, they are able to exploit crosssectional differences across geographic regions to show that the decline in loans had real effects. That is, the pull-back by Japanese banks in local U.S. markets was not fully offset by other lenders stepping in to fill the void.

Taking still a different tack, Peek, Rosengren, and Tootell (2003) obtain evidence of a macroeconomic effect of shifts in bank loan supply. They find that adverse shocks to bank health weaken economic activity in the major GDP components that one would expect to be most affected by bank loan supply shocks - for example, the change in business inventory investment-while not impacting other major components of GDP whose fluctuations would be correlated with demand shocks.

While such aggregate evidence is more than simply suggestive of an operative bank lending channel, to obtain even more convincing evidence about the efficacy of the bank lending channel, one must turn to disaggregated data, preferably at the firm level. One way to test whether bank lending is special is to determine whether a monetary policy tightening disproportionately impacts borrowers that are more reliant on bank lending as a source of external finance. A variety of authors have examined individual firm-level data to determine whether being subject to financial constraints cause nonfinancial firms to react more to 
monetary policy shocks, for example by reducing investment more in response to a monetary policy tightening (for example, Fazzari, Hubbard, and Petersen 1988). The proxies for liquidity constraints have included dividend payouts (Fazzari, Hubbard, and Petersen 1988), size (Gertler and Gilchrist 1994), and bond ratings (Kashyap, Lamont, and Stein 1994). The evidence tends to support the proposition that external funds are more costly to raise than internal funds, so that firms that depend more on external finance are likely to be impacted more adversely by a reduction in bank loan supply.

This, of course, presumes that bank loans are special to firms, so that such loans cannot be replaced easily with nonbank loans or by issuing credit market instruments. A large literature speaks precisely to this point. For example, James (1987) notes that the stock price of a firm rises in response to an announcement of a new loan agreement. Slovin, Sushka, and Poloncheck (1993) observe that the failure of Continental Illinois Bank adversely impacted borrowers that had a close banking relationship with that bank. However, this outcome did not hold if the Continental Illinois loan was part of a loan participation unless Continental Illinois was the lead underwriter of the loan. In terms of the strength of the banking relationship, Petersen and Rajan (1995) note that a firm's banking relationship often involves both a deposit and a lending relationship. They find that the strength of lending relationships, as indicated by a firm holding deposits at the bank, is indicative of how extensively the firm relies on bank lending. Finally, Fields et al. (2006) argue that the value of lending relationships has diminished substantially over time, due in part to the further development of financial markets and the increased availability of information about borrowers. However, their sample includes only publicly traded firms, precisely those firms that are the least likely to be bank dependent. Consistent with the view of Fields et al. (2006), Gande and Saunders (2012) argue that the development of the secondary loan market has reduced to some extent the 'specialness' of banks due to the weakening of banks' incentives to monitor borrowers.

Thus, the evidence from studies based on individual nonfinancial firms supports the proposition that many firms are, in fact, bank dependent, and that their economic activity is adversely affected by reductions in bank loan supply. While other financial intermediaries provide external finance to firms, this credit tends to be directed to specific types of loans. Finance companies tend to focus on asset-backed lending, such as receivables, while 
insurance companies tend to make longer duration loans that match more closely the duration of their liabilities. Thus, banks remain the primary source of funding for smaller firms that lack ready access to external finance from other sources.

\section{Non-U.S. evidence on bank lending and the transmission of monetary policy}

The role of banks in the transmission of monetary policy is potentially more relevant in many other countries because of their relatively greater reliance on bank finance compared with the market-based system of finance in the United States. A good example is Japan, where banks continue to have a significant role in financing large as well as small companies, although because of deregulation of the Japanese bond markets the largest companies are increasingly able to tap directly into financial markets (for example, Hoshi and Kashyap 2001). The Japanese economy also is particularly interesting because of a variety of characteristics that make bank-firm ties especially close; such characteristics include widespread cross-shareholding, bank representatives placed on firms' board of directors, and bank-centered keiretsu groups (see, for example, Kaplan and Minton 1994; Kang and Shivdasani 1995; and Morck and Nakamura 1999).

Even before the Japanese banking problems that began in the early 1990s were able to have their full impact, Hoshi, Scharfstein, and Singleton (1993), using the mix-effect technique with aggregate data, found that when monetary policy tightened, the share of bank loans compared to insurance company loans declined. Furthermore, for Japanese firms not affiliated with bank-centered keiretsu groups, and thus less closely connected to banks, firm liquidity was a more important determinant of these firms' investment when monetary policy tightened and bank credit became less available.

After the stock market and real estate bubbles burst and bank health began to deteriorate, Japanese banks faced with potential capital constraints sought ways to continue to lend to domestic borrowers while still shrinking their balance sheets. Peek and Rosengren $(1997 ; 2000)$ find that global Japanese banks initially shrank their assets abroad in order to insulate their domestic lending. As the Japanese banking problems continued, domestic borrowers and the lending channel were affected. For example, Ito and Sasaki (2002) find evidence of a credit crunch in Japan as binding capital constraints became an important factor in the ability of Japanese banks to continue to lend. Similarly, Kang and Stulz (2000) 
find that the banking problems in Japan had the greatest adverse impact, both in terms of stock prices and in terms of their investment expenditures, on the firms that were the most bank dependent. In addition, several studies argue that problems were compounded by Japanese banks applying international bank capital standards that resulted in the need for Japanese banks to increase their capital ratios (for example, Hall 1993; and Montgomery 2005).

Given the relative importance of bank lending as a source of credit in Japan, it is likely that the severe banking problems weakened the bank lending channel and contributed to the prolonged malaise in the Japanese economy throughout the 1990s and early 2000s, even though monetary policy reduced interest rates to near zero. This was magnified by distortions that had a broader adverse impact on the economy. These distortions had their source in a combination of the prevailing lending relationships and the perverse incentives faced by banks that led to a misallocation of much of the credit that banks provided (Peek and Rosengren 2005). In fact, Caballero, Hoshi, and Kashyap (2008) link the misallocation of credit to broader economic problems in Japan, finding that investment by firms was seriously distorted by the desire of banks to support 'zombie' (insolvent) firms.

Similarly, the evidence suggests that the deterioration in bank health created similar problems when other Asian countries experienced financial difficulties in the late 1990s. For example, Ferri and Kang (1999) find that South Korean problems caused a significant credit crunch when bank capital became constrained. Given that the chaebols (business groups) in Korea have some similarities to the keiretsus in Japan, one might expect that some of the same results found in Japan also would hold in emerging market economies such as Korea. Still, the banking consolidation in emerging market economies in Asia and Latin America has tended to weaken the bank lending channel of monetary policy transmission (Olivero, $\mathrm{Li}$, and Jeon 2011). Moreover, the rise in foreign bank penetration in emerging markets has been another factor weakening the lending channel, given that foreign banks respond less strongly than domestic banks in host countries to host country monetary policy shocks due to the foreign banks' access to funding from their parent organizations, which can insulate them from an adverse liquidity shock in the host country (Wu, Luca, and Jeon 2011).

Europe is somewhere between Japan and the United States in terms of bank dependence. While European countries do not have the formalized banking relationships of the Japanese 
keiretsus to the same degree, Europe has generally been considered to have bank-centered finance. Thus, European firms have not had the same direct access to financial markets as many U.S. firms. However, the conversion to the Euro and the consequent integration and deepening of European financial markets has moved the Euro area to a more market-based model of corporate finance, improving the access of European firms to credit.

Even though bank lending is more important in Europe than in the United States, the evidence on the European bank lending channel is mixed. While Angeloni et al. (2003) find that most of the European evidence is consistent with a classic interest rate channel for the transmission of monetary policy, they do find some country-specific evidence supporting a bank lending channel, with bank loan supply reacting to changes in monetary policy in a number of countries. Ehrmann et al. (2001) also investigate the importance of the bank lending channel in Europe, applying a number of the empirical tests conducted on U.S. data to European data. Consistent with the results in the United States, they find that monetary policy does alter bank loan supply, particularly for those banks that are liquidity constrained. However, they do not find that the size of the bank influences the bank's reaction to a monetary policy shock. Similarly, Gambacorta (2005), using Italian data, finds that a tightening of monetary policy reduces bank lending, with the effect mitigated for banks that are well capitalized, are relatively liquid, or can benefit from the operation of internal capital markets by being affiliated with a bank holding company. Again, bank size is not important.

More recently, a number of studies have specifically addressed the identification challenges that make it particularly difficult to obtain definitive evidence. Becchetti, Garcia, and Trovato (2011), using Italian data, and Jimenez et al. (2012), using Spanish data, base their analyses on individual loan application records. Becchetti, Garcia, and Trovato (2011) investigate the relationship between the European Central Bank refinancing rate and credit rationing by banks, using the difference between the amounts requested by borrowers and the loan amounts granted by the banks. They find that the refinancing rate is positively related to credit rationing, although they conclude that the effect arises from a borrower's balance sheet effect rather than from a bank balance sheet effect. In contrast, Jimenez et al. (2012) use the extensive margin for loan application decisions, finding an inverse 
relationship between short-term interest rates and loan approval that is stronger the weaker is bank health, and concluding that the bank balance sheet effect is operative.

Maddaloni and Peydro (2011) take an alternative approach to addressing the identification challenges by relying on surveys of lending standards (for both the Euro area and the United States). They find that low short-term interest rates soften bank lending standards for loans to both firms and households, reinforcing the lending channel that operates through banks. Moreover, this effect is amplified by securitization. In contrast, Altunbas, Gambacorta, and Marques-Ibanez (2009) argue that the dramatic increase in securitization activity in Europe has weakened the efficacy of the bank lending channel. By increasing banks' access to liquidity and ability to continue lending without expanding their balance sheets, securitization contributes to the ability of banks to insulate their loan supply from the effects of a tightening of monetary policy.

\section{Some observations on recent events}

The severity of the Great Recession and the extremely slow recovery, both in the United States and abroad, in the face of a dramatic and sustained easing of monetary policy have highlighted the importance for the efficacy of monetary policy of the developments we have been discussing. In particular, recent events have re-emphasized the important role of financial intermediaries in the transmission of monetary policy. Particularly striking has been the realization that most standard macroeconomic models had included little or no role for financial institutions, resulting in very poor performance in forecasting events around the financial crisis. Consequently, research in this area has been stimulated by a general agreement that reliance on macroeconomic models with no significant financial sector was a significant flaw in our understanding of macroeconomic dynamics. Adrian and Shin (2011) provide a survey of some of this early research, and Brunnermeier and Sannikov (forthcoming) provide a good example of the difficulties posed by introducing a financial sector into standard macroeconomic models. Moreover, in addition to recognition of the failure of most large macroeconomic models to capture the dynamics of the financial crisis, there has been a significant re-evaluation of the critical role that financial intermediaries can play in the transmission of monetary policy and in amplifying the impact of financial shocks more generally. 
As a consequence, the important role of securitized lending is receiving much more attention. Prior to the financial crisis, it had frequently been assumed that collateralized credit would be stable in a crisis because lenders would remain comfortable lending on a fully collateralized basis. The thinking was that relying less on the credit quality of the borrower, securitized lending would be relatively unaffected by a shock that impacted the perceived credit-worthiness of the borrower. However, the so-called originate-to-distribute model, whereby financial intermediaries make loans that are securitized while retaining a small proportion of the loan, turned out to be a particularly unstable source of financing during the crisis. While securitization can expand the supply of bank loans, it can also increase the cyclicality of the supply of credit and expose highly levered banks to a disruption of the securitization market (for example, Ivashina and Scharfstein 2010b; Loutskina 2011; and Gorton and Metrick 2012). In particular, a drying up of the securitization pipeline can put pressure on bank liquidity, impair new bank lending, and potentially cause fire sales of securities. For example, Shleifer and Vishny (2010) show that if fire sales of securities cause security prices to fall below their fundamental values, banks may choose to hold on to their securities because of the very low valuations and may, in fact, expand their holdings at the expense of lending for new projects. Moreover, as haircuts are increased for repurchase agreements, highly levered financial intermediaries that rely on wholesale funding come under severe stress (for example, Gorton and Metrick 2012; and Adrian and Shin 2009). The consequent deleveraging actions by financial intermediaries further increase the downward pressure on securities valuations. In fact, the inability of most of the large investment banks to fund themselves during the crisis and the spectacular collapse of Bear Stearns and Lehman Brothers provided graphic examples that previous assumptions about the ability to roll over collateralized loans were deeply flawed.

The funding pressure on financial intermediaries was compounded by their increased reliance on wholesale funding. Although the role of financial runs had received very little attention prior to the crisis because it had been assumed that bank runs would likely be contained by deposit insurance, this area of research is being re-examined in light of the different nature of financial runs experienced during the crisis that severely limited credit extension after the failure of Lehman Brothers. A number of studies have highlighted the fact that these less traditional bank runs can have a significant impact on the supply of credit 
and that the effect of these supply constraints depends on the exact nature of the bank's business model. For example, Ivashina and Scharfstein (2010a) show that concerns with credit availability caused borrowers to draw down available lines of credit at the same time as banks themselves were having trouble rolling over their own short-term debt. As might be expected in such a situation, banks less dependent on wholesale funding cut their lending less than banks more dependent on wholesale funding. In fact, Gambacorta and MarquesIbanez (2011) show that a funding model based on short-term market funding can, and did, alter banks' response to changes in monetary policy in both the United States and Europe. Adrian and Shin (2009) similarly note that capital market financing and bank lending behavior performed quite differently during the crisis. Banks that were funded by deposits expanded their credit as customers drew down their lines of credit, while market-based credit and securitization declined significantly as a result of the financial crisis. Going forward, this implies that the strength of the bank lending channel will depend in part on how bank funding models evolve in the wake of the financial crisis, as well as on how new bank regulatory regimes, such as the increasing regulatory attention being placed on the over reliance on wholesale funding by banks, evolve.

While earlier financial problems resulted in the academic literature focusing on the role of capital constraints in potentially impeding bank lending, that literature did not focus on the role of bank liquidity management. One of the key elements of the financial crisis in the fall of 2008 was how quickly banks and firms hoarded liquidity, compounding some of the collateral damage from the failure of large financial institutions. Studies have increasingly highlighted the fact that credit supply can be impeded by banks that are liquidity constrained. For example, Cornett et al. (2011) and Gambacorta and Marques-Ibanez (2011) show that banks were more likely to lend during the crisis if they were well capitalized and had significant core deposits. Banks that held more illiquid assets were less able to continue lending, particularly if their lines of credit were being drawn down by borrowers. Moreover, liquidity problems were an issue not only for banks. One of the motivations for the lending facilities established by the Federal Reserve was to ease liquidity constraints by providing liquidity to nondepository institutions through the Federal Reserve's discount window. One example of this was the run on money market funds after the Reserve Fund announced that it would no longer be able to pay a fixed net asset value to investors. Duygan-Bump et al. 
(2013) describe the role that discount window lending played in reducing the liquidity problems generated by runs on the money market fund industry. Because money market funds were an important source of short-term financing, including to banks, this facility helped relieve liquidity problems beyond just the money market fund industry.

In addition to the evolution of bank business models to rely more on both securitization and wholesale funding to enhance their liquidity, other dramatic changes in the financial environment associated with the financial crisis also are likely to weaken the efficacy of monetary policy operating through the lending channel. In particular, hitting the zero lower bound for short-term interest rates forced the Federal Reserve to rely on unconventional monetary policy actions to stimulate economic activity. The large-scale asset purchases undertaken by the Federal Reserve and other central banks have provided substantial excess reserves to the banking system. As a consequence, the reserve requirement is no longer a binding constraint on bank behavior. Thus, open market purchases of securities are unlikely to have an effect on bank lending through the usual mechanism associated with the lending channel whereby banks would be forced to reduce reservable deposits. Instead, bank lending behavior will likely be governed by capital requirements and the effect of interest rates on the banks' cost of funds and the profitability of lending. In fact, recent studies have emphasized a risk-taking channel for monetary policy that places more emphasis on the willingness of banks to expand their balance sheet (for example, Borio and Zhu 2012; and Adrian and Shin 2011). Adrian and Shin (2011) provide an overview of how changes in risk appetite, which is partly a function of monetary policy, generates a critical link between monetary policy changes, the actions of financial intermediaries, and the impact on the real economy. This connection between bank risk-taking and monetary policy will be an important topic for future research highlighting the role of banks in the conduct of monetary policy, as well as for broader financial stability issues.

\section{Conclusion}

Theoretical and empirical studies produced over the past two decades have emphasized the important role for banks in the transmission of monetary policy. Much of this work has highlighted a role for changes in bank assets in response to a monetary policy shock, above and beyond the familiar interest rate channel operating on the liability side of bank balance sheets. The empirical evidence provides substantial support for the view that liquidity- 
constrained banks and bank-dependent borrowers can be adversely impacted by a tightening of monetary policy. The evidence also indicates that a bank lending channel can be important in an international context, especially in countries where banks and firms have less direct access to financial markets.

In addition, a significant body of research highlights that during bank capital crunches the bank lending channel can be short-circuited. Again, the international evidence indicates that capital-constrained banks make it difficult for monetary policy to have as large an impact as it would have if banks were not capital constrained. Moreover, more recent evidence related to the financial crisis shows that liquidity crunches can similarly shortcircuit the bank lending response to accommodative monetary policy, requiring larger changes in monetary policy instruments to obtain the same desired change in aggregate demand.

As a result of our experiences during the recent financial crisis, we now have a better appreciation for the importance of financial intermediaries, both in their role in the transmission of monetary policy and in their impact on financial stability more generally. Given the extensive need for government support of banks and credit provision more generally, the financial crisis should provide a particularly fruitful laboratory for future research that can improve our understanding of the role of banks in the transmission of monetary policy. While alternative hypotheses are only beginning to be explored and it is too soon to fully evaluate the consequences of the changed financial and regulatory environments associated with the crisis, it is virtually certain that banks will continue to play an important, although changing, role in the transmission of monetary policy as financial markets continue to evolve. 


\section{References}

Adrian, T. and H. S. Shin. 2009. "Money, Liquidity, and Monetary Policy." American Economic Review Papers and Proceedings 99(2): 600-605.

2011. "Financial Intermediaries and Monetary Economics." in Friedman, B. M. and M. Woodford (eds.) Handbook of Monetary Economics 3A, Chapter 12. Amsterdam: Elsevier, 601-650.

Altunbas, Y., L. Gambacorta, and D. Marques-Ibanez. 2009. "Securitization and the Bank Lending Channel." European Economic Review 53(8): 996-1009.

Angeloni, I., A. K. Kashyap, B. Mojon, and D. Terlizzese. 2003. "Monetary Transmission in the Euro Area: Where Do We Stand?" in Angeloni, I., A. K. Kashyap, and B. Mojon (eds.) Monetary Policy Transmission in the Euro Area Cambridge: Cambridge University Press, 383412.

Ashcraft, A. 2005. "Are Banks Really Special? New Evidence from the FDIC-Induced Failure of Healthy Banks." American Economic Review 95: 1712-1730.

2006. "New Evidence on the Lending Channel." Journal of Money, Credit and Banking 38(3): 751-775.

Becchetti, L., M. M. Garcia, and G. Trovato. 2011. "Credit Rationing and Credit View: Empirical Evidence from an Ethical Bank in Italy." Journal of Money, Credit and Banking 43(6): 1217-1245.

Berger, A. N. and G. F. Udell. 1994. "Did Risk-Based Capital Allocate Bank Credit and Cause a 'Credit Crunch' in the United States?" Journal of Money, Credit and Banking 26(3), part II: $585-628$.

Bernanke, B. S. and A. S. Blinder. 1988. "Credit, Money, and Aggregate Demand." American Economic Review Papers and Proceedings 78(2): 435-439.

1992. "The Federal Funds Rate and the Channels of Monetary Transmission." American Economic Review 82(4): 901-921.

Bernanke, B. S., and M. Gertler. 1995. "Inside the Black Box: The Credit Channel of Monetary Policy Transmission." Journal of Economic Perspectives,9(4): 27-48.

Bernanke, B. S., and M. Gertler, and S. Gilchrist. 1996. "The Financial Accelerator and the Flight to Quality." The Review of Economics and Statistics 78(1): 1-15.

Borio, C. and H. Zhu. 2012. "Capital Regulation, Risk-Taking and Monetary Policy: A Missing Link in the Transmission Mechanism?" Journal of Financial Stability 8(4): 236-251. 
Bouwman, C. H. S. 2014. "Liquidity: How Banks Create It and How It Should Be Regulated." in Berger, A., P. Molyneux, and J. O. S. Wilson (eds.) Oxford Handbook of Banking, $2^{\text {nd }}$ edition. Oxford: Oxford University Press, forthcoming.

Brunnermeier, M. K. and Y. Sannikov (forthcoming). "A Macroeconomic Model with a Financial Sector." American Economic Review.

Caballero, R. J., T. Hoshi, and A. K. Kashyap. 2008. "Zombie Lending and Depressed Restructuring in Japan." American Economic Review 98(5): 1943-1977.

Calomiris, C. W. 2014. "The Great Depression and Other Contagious Events." in Berger, A., P. Molyneux, and J. O. S. Wilson (eds.) The Oxford Handbook of Banking, $2^{\text {nd }}$ edition. Oxford: Oxford University Press, forthcoming.

Campello , M. 2002. "Internal Capital Markets in Financial Conglomerates: Evidence from Small Bank Responses to Monetary Policy," Journal of Finance 57(6): 2773-2805.

Caprio, G., Jr. and P. Honohan. 2014. "Banking Crises." in Berger, A., P. Molyneux, and J. O. S. Wilson J. O. S. (eds.) The Oxford Handbook of Banking, $2^{\text {nd }}$ edition. Oxford: Oxford University Press, forthcoming.

Cecchetti, S. G. 1995. "Distinguishing Theories of the Monetary Transmission Mechanism." Federal Reserve Bank of St. Louis Review May/June, 83-97.

Cetorelli, N. and L. S. Goldberg. 2012. "Banking Globalization and Monetary Transmission." Journal of Finance 67(5): 1811-1843.

Cornett, M. M., J. J. McNutt, P. E. Strahan, and H. Tehranian. 2011. “Liquidity Risk Management and Credit Supply in the Financial Crisis." Journal of Financial Economics 101(2): 297-312.

Driscoll, J. O. 2004. "Does Bank Lending Affect Output? Evidence from the U.S. States." Journal of Monetary Economics 51(3): 451-471.

Duygan-Bump, B., P. Parkinson, E. Rosengren, G. Suarez, and P. Willen. 2013. "How Effective Were the Federal Reserve Emergency Liquidity Facilities? Evidence from the AssetBacked Commercial Paper Money Market Mutual Fund Liquidity Facility." Journal of Finance 68(2): 715-737.

Ehrmann, M., L. Gambacorta, J. Martinez-Pages, P. Sevestre, and A. Worms. 2001. "Financial Systems and the Role of Banks in Monetary Policy Transmission in the Euro Area." European Central Bank Working Paper 105.

Fazzari, S. M., R. G. Hubbard, and B. C. Petersen. 1988. "Financing Constraints and Corporate Investment." Brookings Papers on Economic Activity 141-195. 
Ferri, G. and T. S. Kang. 1999. "The Credit Channel at Work: Lessons from the Republic of Korea's Financial Crisis" World Bank Policy Research Working Paper 2190.

Fields, L. P., D. R. Fraser, T. L. Berry, and S. Byers, S. 2006. “Do Bank Loans Relationships Still Matter?" Journal of Money, Credit and Banking 38(5): 1195-1209.

Gambacorta, L. 2005. “Inside the Bank Lending Channel." European Economic Review 49(7): 1737-1759.

Gambacorta, L. and D. Marques-Ibanez. 2011. "The Bank Lending Channel: Lessons from the Crisis." BIS Working Paper No. 345, May.

Gande, A. and A. Saunders. 2012. "Are Banks Still Special When There Is a Secondary Market for Loans?" Journal of Finance 67(5): 1649-1684.

Gertler, M. and S. Gilchrist. 1993. "The Role of Credit Market Imperfections in the Monetary Transmission Mechanism: Arguments and Evidence." The Scandinavian Journal of Economics 95(1): 43-64.

1994. "Monetary Policy, Business Cycles, and the Behavior of Small Manufacturing Firms." The Quarterly Journal of Economics 109(2): 309-340.

Gorton, G. and A. Metrick. 2012. "Securitized Banking and the Run on Repo." Journal of Financial Economics 104(3): 425-451.

HAlL, B. J. 1993.“How Has the Basel Accord Affected Bank Portfolios?” Journal of the Japanese and International Economies 7(4): 408-440.

Hancock, D. and J. A. Wilcox. 1994. "Bank Capital and the Credit Crunch: The Roles of RiskWeighted and Unweighted Capital Regulation." Journal of the American Real Estate and Urban Economics Association 22(1): 59-94.

Holod, D. and J. Peek . 2007. “Asymmetric Information and Liquidity Constraints: A New Test." Journal of Banking \& Finance 31(8): 2425-2451.

Hoshi, T. and A. N. Kashyap. 2001. Corporate Financing and Governance in Japan. Cambridge, MA: MIT Press.

Hoshi, T., D. Scharfstein, and K. J. Singleton. 1993. “Japanese Corporate Investment and Bank of Japan Guidance of Commercial Bank Lending." in Singleton, K. J. (ed.) Japanese Monetary Policy Chicago: University of Chicago Press, 63-94.

Hubbard, R. G. 1995. “Is There a 'Credit Channel' for Monetary Policy?” Federal Reserve Bank of St. Louis Review May/June, 63-77. 
Ito, T. and Y. N. Sasaki . 2002. "Impacts of the Basel Capital Standard on Japanese Banks' Behavior." Journal of the Japanese and International Economies 16(3): 372-397.

Ivashina, V. and D. Scharfstein. 2010a. "Bank Lending during the Financial Crisis of 2008." Journal of Financial Economics 97(3): 319-338.

2010b. "Loan Syndication and Credit Cycles." American Economic Review Papers and Proceedings 100(2): 57-61.

James, C. 1987. "Some Evidence on the Uniqueness of Bank Loans." Journal of Financial Economics 19(2): 217-235.

Jimenez, G., S. Ongena, J. L. Peydro, and J. Saurina. 2012. “Credit Supply and Monetary Policy: Identifying the Bank Balance-Sheet Channel with Loan Applications." American Economic Review 102(5): 2301-2326.

Kang, J. K. and A. Shivdasani. 1995. "Firm Performance, Corporate Governance, and Top Executive Turnover in Japan," Journal of Financial Economics, 38(1): 29-58.

Kang, J. K. and R. M. Stulz. 2000. “Do Banking Shocks Affect Borrowing Firm Performance? An Analysis of the Japanese Experience." Journal of Business 73(1): 1-23.

Kaplan, S. N. and B. A. Minton. 1994. "Appointments of Outsiders to Japanese Boards: Determinants and Implications for Managers." Journal of Financial Economics 36(2): 225-258.

Kashyap, A. K., O. A. Lamont, and J. C. Stein. 1994. "Credit Conditions and the Cyclical Behavior of Inventories," The Quarterly Journal of Economics, 109(3): 565-592.

Kashyap, A. K. and J. C. Stein. 1994. "Monetary Policy and Bank Lending." in Mankiw, N. G. (ed.) Monetary Policy Chicago: University of Chicago Press, 221-256.

. 1995. "The Impact of Monetary Policy on Bank Balance Sheets." CarnegieRochester Conference Series on Public Policy 42(1): 151-195.

. 2000. "What Do a Million Observations on Banks Say about the Transmission of Monetary Policy?" American Economic Review 90(3): 407-428.

2004."Cyclical Implications of the Basel II Capital Standard." Federal Reserve Bank of Chicago Economic Perspectives First Quarter, 18-31.

Kashyap, A. K., J. C. Stein, and D. W. Wilcox. 1993. “Monetary Policy and Credit Conditions: Evidence from the Composition of External Finance." American Economic Review 83(1): 78-98.

1996. "Monetary Policy and Credit Conditions: Evidence from the Composition of External Finance: Reply." American Economic Review 86(1): 310-314. 
Kishan, R. P. and T. P. Opiela. 2000. "Bank Size, Bank Capital, and the Bank Lending Channel." Journal of Money, Credit and Banking 32(1): 121-141.

Loutskina, E. 2011. "The Role of Securitization in Bank Liquidity and Funding Management." Journal of Financial Economics 100(3): 663-684.

Loutskina, E. and P. Strahan, P. 2009. "Securitization and the Declining Impact of Bank Finance on Loan Supply: Evidence from Mortgage Originations." Journal of Finance 64(2): 861-889.

Ludvigson, S. 1998. "The Channel of Monetary Transmission to Demand: Evidence from the Market for Automobile Credit." Journal of Money, Credit and Banking 30(3): 365-383.

Maddaloni, A. and J. L. Peydro. 2011. "Bank Risk-Taking, Securitization, Supervision, and Low Interest Rates: Evidence from the Euro-Area and the U.S. Lending Standards." Review of Financial Studies, 24(6): 2121-2165.

Montgomery, H. 2005. "The Effect of the Basel Accord on Bank Portfolios in Japan." Journal of the Japanese and International Economies 19(1): 24-36.

Morck, R. and M. Nakamura. 1999. "Banks and Corporate Control in Japan." Journal of Finance 54(1): 319-339.

Morgan, D. P. 1998. "The Credit Effect of Monetary Policy: Evidence Using Loan Commitments." Journal of Money, Credit and Banking 30(1): 102-118.

Oliner, S. D. and G. D. Rudebusch. 1996a. "Is There a Broad Credit Channel for Monetary Policy?" Federal Reserve Bank of San Francisco Economic Review 1: 3-13.

. 1996b. "Monetary Policy and Credit Conditions: Evidence from the Composition of External Finance: Comment." American Economic Review 86(1): 300-309.

Olivero, M. P., Y. Li, and B. N. Jeon. 2011. "Consolidation in Banking and the Lending Channel of Monetary Transmission: Evidence from Asia and Latin America." Journal of International Money and Finance 30(6): 1034-1054.

Peek, J. and E. S. Rosengren. 1995a. "The Capital Crunch: Neither a Borrower nor a Leader Be." Journal of Money, Credit and Banking 27(3): 625-638.

. 1995b. "Bank Regulation and the Credit Crunch." Journal of Banking $\mathcal{E}$ Finance 19(3-4): 679-692.

. 1997. "The International Transmission of Financial Shocks: The Case of Japan." American Economic Review 87(4): 495-505. 
. 2000. "Collateral Damage: Effects of the Japanese Bank Crisis on Real Activity in the United States." American Economic Review 90(1): 30-45.

. 2005. "Unnatural Selection: Perverse Incentives and the Misallocation of

Credit in Japan." American Economic Review 95(4): 1144-1166.

Peek, J., E. S. Rosengren, and G. M. B. Tootell. 2003. "Identifying the Macroeconomic Effect of Loan Supply Shocks." Journal of Money, Credit and Banking 35(6, Part I): 931-946.

Petersen, M. A. and R. G. Rajan. 1995. "The Effect of Credit Market Competition on Lending Relationships." The Quarterly Journal of Economics 110(2): 407-443.

Romer, C. D. and D. H. Romer. 1990. "New Evidence on the Monetary Transmission Mechanism." Brookings Papers on Economic Activity 1: 149-213.

Shleifer, A. and R. W. Vishny. 2010. "Asset Fire Sales and Credit Easing." American Economic Review Papers and Proceedings 100(2): 46-50.

Slovin, M. B., M. E. Sushka, and J. A. Polonchek. 1993. "The Value of Bank Durability: Borrowers as Bank Stakeholders." Journal of Finance 48(1): 247-266.

Strahan, P. E. 2009. "Liquidity Production in Twenty-first-Century Banking," in Berger, A., P. Molyneux, and J. O. S. Wilson, (eds.) Oxford Handbook of Banking. Oxford: Oxford University Press, 112-145.

Wu, J., A. C. Luca, and B. N. Jeon. 2011. “Foreign Bank Penetration and the Lending Channel in Emerging Economies: Evidence from Bank-Level Panel Data." Journal of International Money and Finance 30(6): 1128-1156. 